\title{
AGRONOMIC AND ECONOMIC PERFORMANCE OF GENETICALLY MODIFIED AND CONVENTIONAL MAIZE
}

\author{
KATARÍNA HRČKOVÁ ${ }^{1}$, PETER MIHALČÍI ${ }^{1}$, ŠTEFAN ŽÁK ${ }^{1}$, ROMAN HAŠANA ${ }^{1}$, \\ KATARÍNA ONDREIČKOVÁ ${ }^{1}$, JÁN KRAIC ${ }^{1,2^{*}}$
}

\author{
${ }^{1}$ National Agricultural and Food Centre, Research Institute of Plant Production, Piešt'any, Slovakia \\ ${ }^{2}$ University of Ss. Cyril and Methodius, Faculty of Natural Sciences, Slovakia
}

HRČKOVÁ, K. - MIHALČÍK, P. - ŽÁK, Š. - HAŠANA, R. - ONDREIČKOVÁ, K. - KRAIC, J.: Agronomic and economic performance of genetically modified and conventional maize. Agriculture (Pol'nohospodárstvo), vol. 64, 2018, no. 2, pp. 87-93.

The parameters determining the agronomic and economic performance of genetically modified maize hybrid MON $89034 \times$ NK603 and conventional hybrids were compared under conditions that eliminated the herbicide tolerance in GM hybrid as well as the use of insecticides in conventional hybrids. The GM hybrid confirmed ability to protect itself against the European corn borer and its average grain yield was higher by $6.36-14.42 \%$ (i.e. $0.82-1.86 \mathrm{t} / \mathrm{ha}$ ) in comparison with conventional hybrids. The year of cultivation statistically significant influenced agronomic parameters and the financial income of maize production. The maize genotype did not statistically significantly affected any evaluated parameter. The final income was statistically significant $(P<0.05)$ negatively influenced by all observed agronomic parameters with the exception of the seed price. The price of maize grains on the market was the only one factor that statistically significant $(P<0.05)$ influenced financial income of the maize production.

Key words: maize, genetically modified hybrid, grain production, economic benefit

The genetically modified (GM) maize (Zea mays L.) has been commercially grown since the year 1996 and it still belongs to four GM "megacrops". Nevertheless, farmers in the European Union (EU) may not cultivate GM maize with any genetic modification except of the MON 810 resistant to European corn borer [ECB, Ostrinia nubilalis (Hübner)]. The genetic potential, agronomic traits and economic benefits of others GM maize cultivars and hybrids are unknown to them. However, conventional hybrids without genetic modifications are also able to provide high yield of grains and phytomass, but they need efficient protection against weeds, pests, and pathogens, usually by chemical pesticides. Reports on the economic performance of GM maize resistant against the ECB by virtue of the expression of transgene encoding the $B t$-toxin from Bacillus thuringiensis have been published. According to Lauer and Wedberg (1999) and Marra et al. (2003) the yield of Bt-hybrids was unaffected by the ECB infestation and under the natural infestation was similar to conventional hybrids. Moreover, economic effects were very variable due to the large differences in geographical incidences of the ECB. Graeber et al. (1999) concluded that under low infestation of ECB the $B t$-hybrids had similar yield and agronomic performance to their non- $B t$ near-isolines. On the other side, under high pressure of the ECB, the $B t$-hy-

Ing. Katarína Hrčková, Ing. Peter Mihalčík, Ing. Štefan Žák, CSc., Ing. Roman Hašana, PhD., Mgr. Katarína Ondreičková, PhD., prof. RNDr. Ján Kraic, PhD. ( ${ }^{*}$ Corresponding author), National Agricultural and Food Centre, Research Institute of Plant Production, Bratislavská cesta 122,92168 Piešt’any, Slovak Republic. E-mail: hrckova@vurv.sk, hasana@vurv.sk, ondreickova@vurv.sk,kraic@vurv.sk prof. RNDr. Ján Kraic, PhD., University of Ss. Cyril and Methodius, Faculty of Natural Sciences, Nám. J. Herdu 2, 90701 Trnava, Slovak Republic 
brids had a $9 \%$ yield advantage over non- $B t$ hybrids (Traore et al. 2000). Ma and Subedi (2005) reported that some of tested $B t$-hybrids produced a similar or up to $12 \%$ lower grain yields in comparison with their non- $B t$ counterpart, also when the stalk lodging and breakage of the non-Bt counterpart by the ECB was low to moderate. Field experiments performed in South Africa (Gouse et al. 2005) and Spain (Gómez-Barbero et al. 2008) reported that yield advantage of the $B t$-maize was associated with reduced pesticide costs and increased income per hectare.

The ECB resistant and glyphosate tolerant GM maize hybrid MON $89034 \times$ NK603 should provide agronomic benefit, especially under ECB natural infestation as well as the higher flexibility in weed management during the growing season. Its advantages under lower infestation of the ECB and modest requirements for weed elimination should be limited.

The aim of our field study was to compare performance of conventional maize hybrids with the GM hybrid MON $89034 \times$ NK603 in the main parameters determining the economic effect of grain production, but under conditions eliminating herbicide tolerance of the GM hybrid as well as insecticide applications in conventional hybrids.

\section{MATERIAL AND METHODS}

\section{Field trials}

The field experiments were performed at the experimental station in Borovce (Research Institute of Plant Production, Slovakia) in years 2011-2012. The soil type in the locality is Luvi-haplic Chernozem, the $\mathrm{pH}$ range is 5.5-7.2, the depth of topsoil is $0.24-0.28 \mathrm{~m}$, and content of humus is $1.8-2.0 \%$.

The GM hybrid MON $89034 \times$ NK603 (trade name: Genuity ${ }^{\circledR}$ VT Double Pro ${ }^{\mathrm{TM}}$, Monsanto Company, St. Louis, USA) tolerant to herbicide glyphosate and resistant against lepidopteran insects and conventional hybrids PR36V52 (DuPont Pioneer, Johnston, USA), LG 3475 (Limagrain, Saint Beauzire, France), NK Columbia (Syngenta, Basel, Switzerland), DKC 5143 (Monsanto Company, St. Louis, USA) were sown for the comparison study.

The harvested area of each experimental plot was
$600 \mathrm{~m}^{2}$. Plots were organized by the method of random sub-blocks in four repetitions. Soil was managed conventionally with ploughing in autumn and fertilization before sowing by Polidap ${ }^{\circledR}(200 \mathrm{~kg} / \mathrm{ha})$ containing mainly ammonium hydrogen phosphate (Grupa Azoty Zakłady Chemiczne "Police" S.A., Poland) and urea (130 kg/ha). Only the herbicide Guardian $^{\circledR}$ Tetra $[214 \mathrm{~g} / 1$ Terbuthylazine, $450 \mathrm{~g} / 1$ Acetochlor] (DuPont Pioneer, Johnston, USA) (3.5 1/ha) or a tank mix of MaisTer ${ }^{\circledR}$ power [31.5 g/l Foramsulfuron, $1.0 \mathrm{~g} / 1$ Iodosulfuron, $10 \mathrm{~g} / 1$ Thiencarbazone, $15 \mathrm{~g} / 1$ Cyprosulfamide] (Bayer AG, Leverkusen, Germany) (150 g/ha) with Istroekol (Duslo a.s., Šal'a, Slovakia) (2.0 1/ha) were applied pre-emergently. Grains were harvested by the Claas Lexion 550 (Class GmbH \& Co. KGaA, Harsewinkel, Germany) and after the harvest were deteriorated by squeezer press machine and ploughed into the soil. The grain yields were calculated at standard moisture content $14 \%$.

Phenological and morphological traits, resistance against the ECB, and economical parameters of production were evaluated. Economic parameters included the price of seeds (according to the valid price lists at that time), the yield of grains, and the price of grain production sold (according to the market prices quoted on the Commodity Exchange Bratislava on Dec 13, 2011 and Dec 18, 2012, respectively).

Obtained data were processed by the analysis of variance (ANOVA) and correlation analysis with Spearman rank correlation using the software Statgraphics ${ }^{\circledR}$ Centurion XVII (Statpoint Technologies Inc., The Plains, USA). The Fisher's least significant differences $(L S D)$ were estimated for $\alpha=0.05$ and $\alpha=0.01$.

\section{RESULTS AND DISCUSSION}

Hybrids were tested during two years with different climatic conditions (air temperature, total precipitation, and distribution of precipitation during growing season, Figure 1). Differences in number of germinated plants, number of sterile plants, full flowering of male flowers, length of vegetative period, plant height, perimeter of the main stalk, yield of phytomass, length of cob, number of rows 
in cob, number of grains per row, length of corridors in stalk per plant, number of larvae and pupae per plant, and rate of damaged stalks were not statistically significant, neither between years, nor between maize genotypes. There were evaluated parameters the most related to grain yield as the number of cobs per hectare, thousand grains weight (TGW), grain yield, and resistance against ECB (number of corridors in the stalk, number of plants infested by the $\mathrm{ECB}$, frequency of broken plants, and a number of larvae and pupae in stalks per 100 plants).

\section{Number of cobs per hectare}

This parameter has been observed before grain harvest. The range in number of cobs per hectare was 62,913-75,102 and GM hybrid had the lowest value in both years. Different years affected this parameter statistically significant $(P<0.05)$ however, maize genotypes affected the number of cobs per hectare insignificantly.

\section{Thousand grains weight}

TGW ranged during two years from $240.9 \mathrm{~g}$ to 334.6 g. The GM hybrid had the highest TGW in both years. Better climatic conditions for development of this parameter were in the year 2011 (average TGW $318.4 \mathrm{~g}$ ), worse in 2012 (average TGW $249.8 \mathrm{~g}$ ). TGW was affected statistically significant $(P<0.05)$ by years, differences among maize genotypes not.

\section{Yield of grains}

The highest two-year average yield had GM hybrid (12.90 t/ha), conventional hybrids were in the range 11.04-12.08 t/ha. The years of testing were statistically significant different $(P<0.05)$ and also statistically significantly $(P<0.05)$ affected the grain yield of tested maize genotypes. On the contrary, all maize hybrids responded to climate conditions almost uniformly and differences in grain yield between them were statistically insignificant. The GM hybrid behaved as equivalent of conventional hybrids in the grain yield, even though it could not express its genetic potential to tolerate herbicide glyphosate.

\section{Resistance against the ECB}

The presence of the ECB was found at testing locality in both years. Tested hybrids were infested, except of the resistant GM hybrid. Number of corridors in stalk per plant varied from zero (only in GM hybrid) to 2.4. Differences in number of corridors in stalk per plant were not statistically significant $(P<$ 0.05 ) between years as well as between hybrids. The GM hybrid plants were infested by the ECB in frequency $0-1.7 \%$ (measured as frequency of holes on the stalks and cobs). Level of infestation in conventional hybrids was in the range $28.3-72.5 \%$. Higher infestation (60.8-72.5\%) was in the growing season 2011, lower in 2012 (28.3-37.5\%) however, differences between years as well as between hybrids in

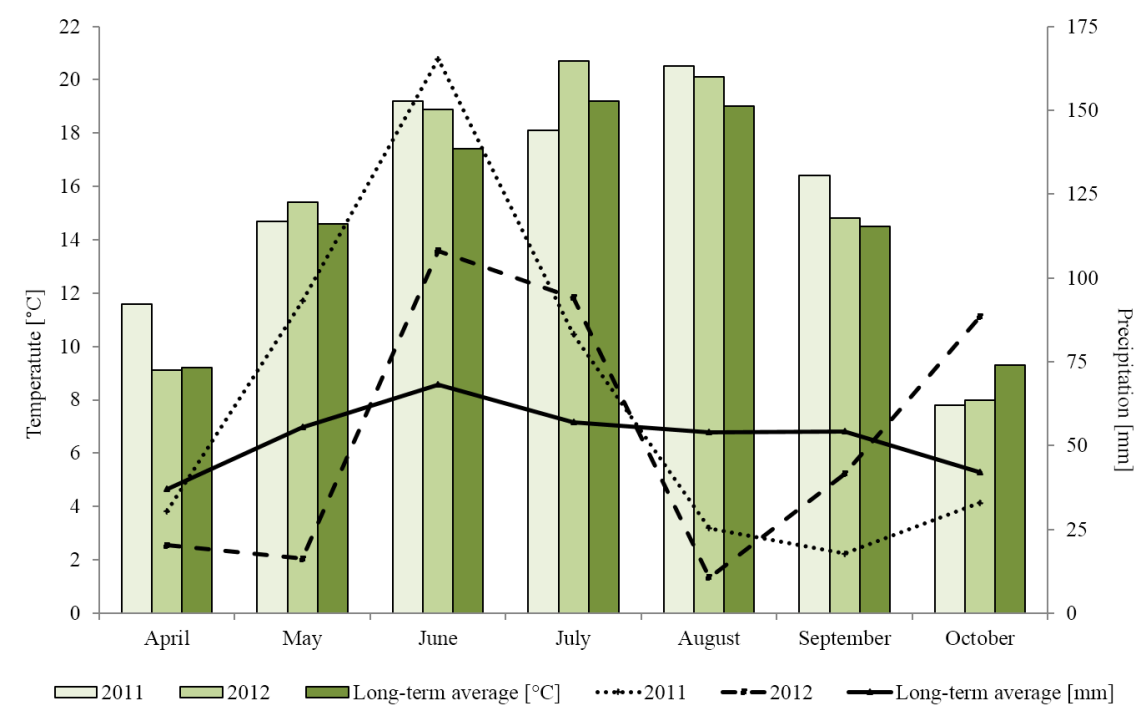

Figure 1. Average monthly temperature and precipitation in testing locality during both vegetation seasons 
this parameter were not statistically significant $(P<$ 0.05). Attack of the ECB has been manifested also by the breakage of plant stalk. Conventional hybrids had $1.7-13.3 \%$ of plants with stalks broken under the cob, the GM hybrid had no broken stalk. Differences between years in this parameter were statistically significant $(P<0.05)$, but between maize genotypes were statistically insignificant. The average abundance of larvae and pupae in stalks per 100 plants of conventional hybrids was high in the year $2011(64.8 \%)$, lower in the year 2012 (32.3\%), in GM hybrid was none. The GM hybrid confirmed its ability to protect itself against ECB. Frequency of infestation by the ECB, number of corridors created by the larvae, and relevant number of broken stalks, statistically insignificantly influenced the average grain yield due to different abundance of the ECB in both years at the experimental location.

\section{Economic assessment}

The economic evaluation was based on the grain production. Both, the two-year average grain yield and income were the highest in the GM hybrid (Figure 2,3). Differences in income between two years were statistically significant $(P<0.05)$, differences between hybrids not. The final income was in significant negative relationship $(P<0.05, P<0.01)$ to the all observed agronomic parameters with the ex-

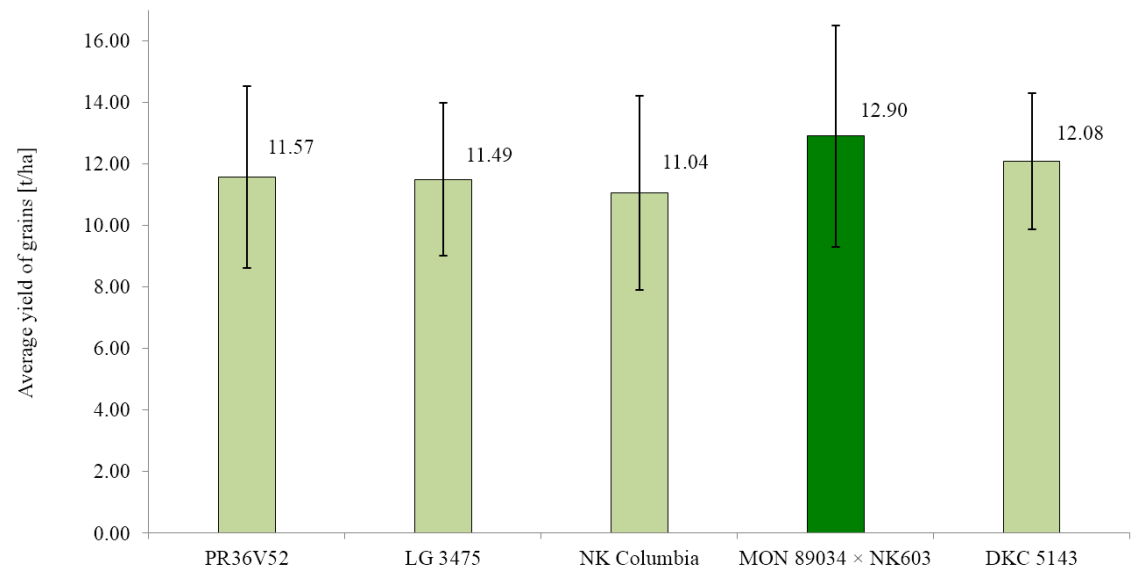

Figure 2. The average grain yield [t/ha] from both years of GM hybrid (dark column) and conventional hybrids (light columns). The values represent the means ( \pm standard error). Differences were statistically insignificant $(P>0.05)$

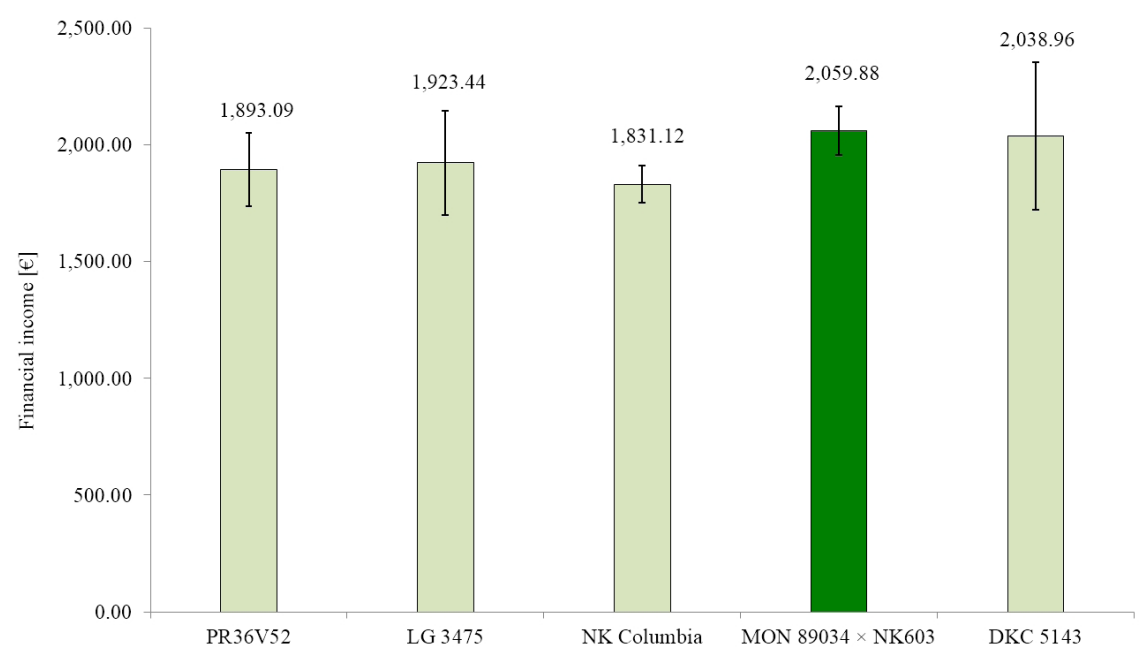

Figure 3. The average financial income $(€)$ from both years of GM hybrid (dark column) and conventional hybrids (light columns) seeds sold ( \pm standard error). Differences were statistically insignificant $(P>0.05)$ 


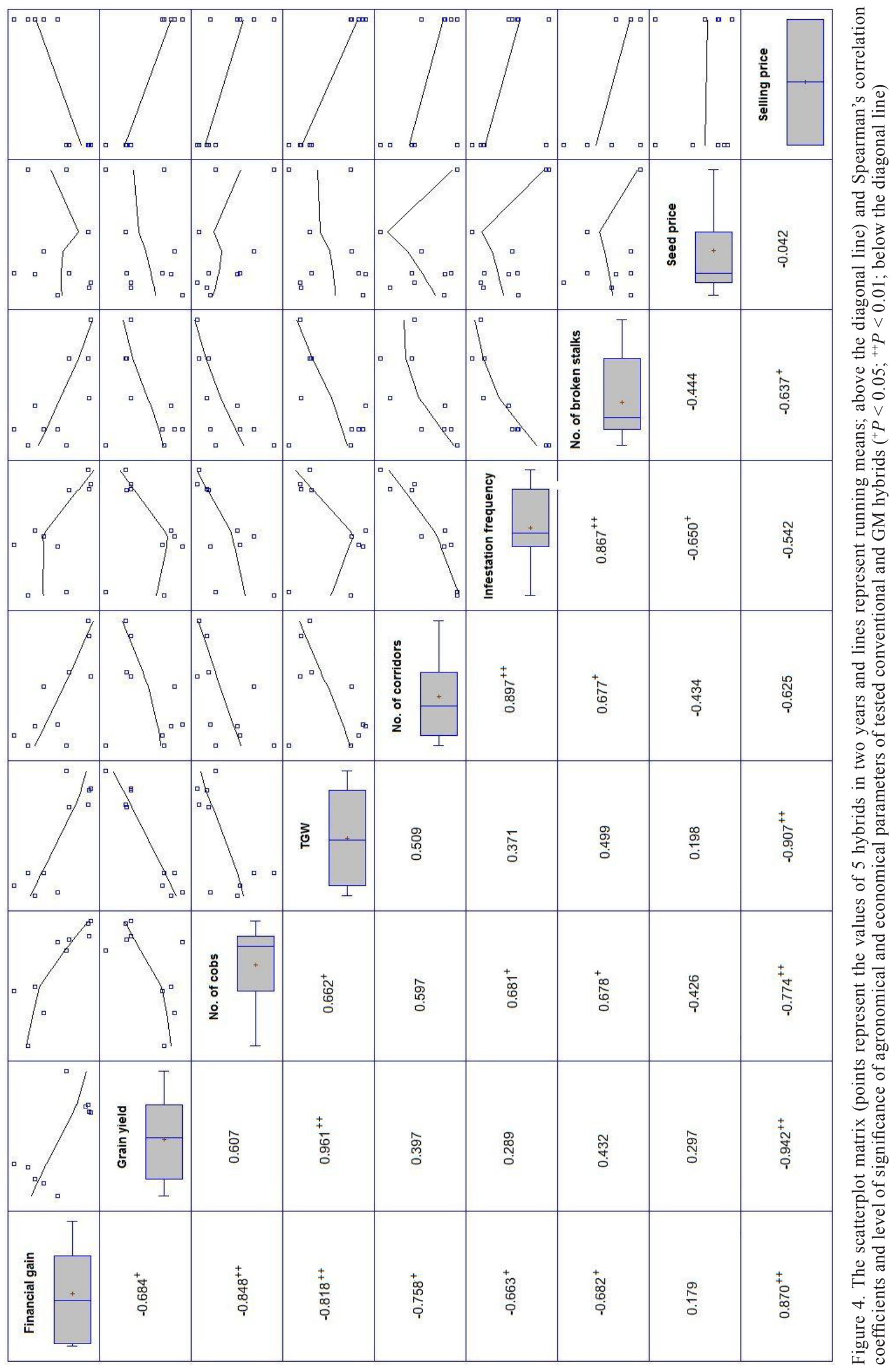


ception of seed price (Figure 4). The most expensive were the seeds of the GM hybrid, with price higher by $18.3-50.4 \%$ in comparison with conventional hybrids. It was not proven by our results that that higher seed price of GM hybrid is the main reason why to do not pay to grow them. This initial investment was not statistically significant from the point of view of the final income. Neither the year, nor the hybrid determined the income gained from the grain production and its sale. The only factor that influenced positively and significantly $(P<0.05)$ the financial income was the price of commodity (i.e. maize grains) on the market (Figure 4).

Tested GM hybrid MON $89034 \times$ NK603 has behaved in the field conditions as an equivalent to conventional hybrids. Its resistance against the ECB and yield parameters were similar to $B t$-maize $\mathrm{MON}$ 810 tested previously in Poland, Czech Republic, and Slovakia (Bereś 2010; Kocourek \& Stará 2012; Mihalčík et al. 2012), as well as to other maize $B t$-hybrids tested in Canada (Yanni et al. 2011). The average abundance of the ECB at our testing location was not very high. Therefore, the resistance against ECB could not very distinctly affect yield of grains (Mungai et al. 2005). An economic return should be realized only when the density of ECB is enough to cause economic loss greater than the premium paid for the transgenic seeds (Rice \& Pilcher 1998). Both of these conclusions have been reflected in our results. However, there are also others emergent effects of $B t$-maize growing as association with area - wide suppression of ECB population and related savings for conventional maize growers (Hutchinson et al. 2010). Moreover, significantly lower concentrations of mycotoxins produced by Fusarium spp. are found in Bt-hybrids (Papst et al. 2004; Ostry et al. 2010). The stacked GM hybrid MON $89034 \times$ NK603 possess also tolerance to glyphosate, but the effect of this transgenic trait on economic performance was not analyzed in our study, although it is known that the application of glyphosate in MON $89034 \times$ NK603 can result to higher grain yield by around 37\% (Ravisankar et al. 2011). Díaz et al. (2017) reported that the GM hybrid MON $89034 \times$ NK603 itself provides economic gain to farmers through higher yields, reduction of production cost for pest control as well as benefit for the environment. Our results present that limits for growing of GM hybrids are not in terms of their grain yield, the quality of production, and economic efficiency. Xu et al. (2013) concluded that adoption of genetically engineered traits had a strong positive impact on maize yield in the Central Corn Belt in the USA generally. According to Jones et al. (2017) adoption of GM crops could make a positive contribution to competitiveness in any EU country that adopts them. However, this is strongly limited by strict and complicated legislation in the EU that is the main reason for their non-adoption by agricultural practice.

\section{CONCLUSIONS}

The GM maize hybrid MON $89034 \times$ NK603 demonstrated equivalency with conventional hybrids in all agronomic traits and economic parameter (income) of grain production. It expressed effectively self-resistance against the ECB. Climatically different growing seasons significantly affected the yield of grain, but all hybrids, including the GM one, responded almost uniformly and differences in grain yield between them were insignificant. Neither the year of cultivation and the genotype, nor the grain yield affected the final economic income, of maize grain production, in contrast to the selling price of maize grains on the market.

Acknowledgements. Funding of this study has been provided by the project ITMS 26210120039 "Systems biology for protection, reproduction and use of plant resources of Slovakia" from the Operational Programme Research and Development co-financed by the European Regional Development Fund.

\section{REFERENCES}

BEREŚ, P.K. 2010. Harmfulness of Ostrinia nubilalis Hbn. on some non-Bt versus genetically modified Bt maize (Zea mays L.) cultivars in Poland in 2006-2007. In Journal of Plant Protection Research, vol. 50, no. 1, pp. 110-116. DOI: $10.2478 / \mathrm{v} 10045-010-0019-\mathrm{z}$

DÍAZ, O.H. - ALDABA MEZA, J.L. - BALTAZAR, B.M. - BOJÓRQUEZ, G.B. - CASTRO ESPINOZA, L. - CORRALES MADRID, J.L. - DE LA FUENTE MARTÍNEZ, J.M. - DURÁN POMPA, H.A. - ALONSO ESCOBEDO, J. - ESPINOZA BANDA, A. - GARZÓN 
TIZNADO, J.A. - GONZÁLEZ GARCÍA, J. - GUZMÁN RODRÍGUEZ, J.L. - MADUEÑO MARTÍNEZ, J.I. MARTÍNEZ CARRILLO, J.L. - MENG, C. - QUIÑONES PANDO, F.J. - ROSALES ROBLES, E. - RUIZ HERNÁNDEZ, I. - TREVIÑO RAMÍREZ, J.E. - URIBE MONTES, H.U. - ZAVALA GARCÍA, F. 2017. Plant characterization of genetically modified maize hybrids MON-89Ø34-3 × MON-88Ø17-3, MON-89Ø34-3 × MONØØ6Ø3-6, and MON-ØØ6Ø3-6: alternatives for maize production in Mexico. In Transgenic Research, vol. 26, no. 1, pp. 135-151. DOI: 10.1007/s11248-016-9991-z

GÓMEZ-BARBERO, M. - BERBEL, J. - RODRÍGUEZCEREZO, E. 2008. Bt corn in Spain - the performance of the EU's first GM crop. In Nature Biotechnology, vol. 26, no. 4, pp. 384-386. DOI: $10.1038 /$ nbt0408-384

GOUSE, M. - PRAY, C.E. - KIRSTEN, J. SCHIMMELPFENNIG, D. 2005. A GM subsistence crop in Africa: the case of Bt white maize in South Africa. In International Journal of Biotechnology, vol. 7, no. 1-3, pp. 84-94. DOI: 10.1504/IJBT.2005.006447

GRAEBER, J.V. - NAFZIGER, E.D. - MIES, D.W. 1999. Evaluation of transgenic Bt-containing corn hybrids. In Journal of Production Agriculture, vol. 12, no. 4, pp. 659663. DOI: 10.2134/jpa1999.0659

HUTCHISON, W.D. - BURKNESS, E.C. - MITCHELL, P.D. - MOON, R.D. - LESLIE, T.W. - FLEISCHER, S.J. - ABRAHAMSON, M. - HAMILTON, K.L. - STEFFEY, K.L. - GRAY, M.E. - HELLMICH, R.L. - KASTER, L.V. - HUNT, T.E. - WRIGHT, R.J. - PECINOVSKY, K. - RABAEY, T.L. - FLOOD, R.R. - RAUN, E.S. 2010. Areawide suppression of European corn borer with Bt maize reaps savings to non-Bt maize growers. In Science, vol. 330, no. 6001 , pp. 222-225. DOI: $10.1126 /$ science. 1190242

JONES, P.J. - MCFARLANE, L.D. - PARK, J.R. - TRANTER, R.B. 2017. Assessing the potential economic benefits to farmers from various GM crops becoming available in the European Union by 2025: Results from an expert survey. In Agricultural Systems, vol. 155, pp. 158-167. DOI: 10.1016/j.agsy.2017.05.005

KOCOUREK, F. - STARÁ, J. 2012. Efficacy of Bt maize against European corn borer in Cetral Europe. In Plant Protection Science, vol. 48, pp. S25-S35.

LAUER, J. - WEDBERG, J. 1999. Grain yield of initial Bt corn hybrid introductions to farmers in the Northern corn belt. In Journal of Production Agriculture, vol. 12, no. 3, pp. 373-376. DOI: 10.2134/jpa1999.0373

MA, B.J. - SUBEDI, K.D. 2005. Development, yield, grain moisture and nitrogen uptake of Bt corn hybrids and their conventional near-isolines. In Field Crops Research, vol. 93, no. 2-3, pp. 199-211. DOI: 10.1016/j.fcr.2004.09.021

MARRA, M. - PANNELL, D.J. - ABADI GHADIM, A. 2003 The economics of risk, uncertainty and learning in the adoption of new agricultural technologies: Where are we on the learning curve? In Agricultural Systems, vol. 75, no. 2-3, pp. 215-234. DOI: 10.1016/S0308-521X(02)00066-5 MIHALČIK, P. - HRČKOVÁ, K. - SINGER, M. PLAČKOVÁ, A. - KRAIC, J. 2012. Effect of MON 810 cultivation and prevention to adventitious presence in nonGM fields: A case study in Slovakia. In Plant Protection Science, vol. 48, pp. S11-S17.

MUNGAI, N.W. - MOTAVALLI, P.P. - NELSON, K.A. - KREMER, R.J. 2005. Differences in yields, residue composition and $\mathrm{N}$ mineralization dynamics of $\mathrm{Bt}$ and nonBt maize. In Nutrient Cycling in Agroecosystems, vol. 73, no. 1, pp. 101-109. DOI: 10.1007/s10705-005-8850-8

OSTRY, V. - OVESNA, J. - SKARKOVA, J. - POUCHOVA, V. - RUPRICH, J. 2010. A review on comparative data concerning Fusarium mycotoxins in $\mathrm{Bt}$ maize and non-Bt isogenic maize. In Mycotoxin Research, vol. 26, no. 3, pp. 141-145. DOI: $10.1007 / \mathrm{s} 12550-010-0056-5$

PAPST, C. - UTZ, H.F. - MELCHINGER, A.E. - EDER, J. MAGG, T. - KLEIN, D. - BOHN, M. 2004. Mycotoxins produced by Fusarium spp. in isogenic Bt vs. non-Bt maize hybrids under European corn borer pressure. In Agronomy Journal, vol. 97, no. 1, pp. 219-224. DOI:10.2134/ agronj2005.0219

RAVISANKAR, D. - MUTHUKRISHNAN, P. CHINNUSAMY, C. 2011. Evaluation of bio-efficacy, weed control and crop productivity in herbicide resistant transgenic corn hybrids (MON $89034 \times$ NK603). In Biotechnology Bioinformatics and Bioengineering, vol. 1, pp. 369-374.

RICE, M.E. - PILCHER, C.D. 1998. Potential benefits and limitations of transgenic Bt corn for management of the European corn borer (Lepidoptera: Crambidae). In Americal Entomologist, vol. 44, no. 2, pp. 75-78. DOI: 10.1093/ae/44.2.75

TERORE, S.B. - CARLSON, R.E. - PILCHER, C.D. - RICE, M.E. 2000. Bt and non-Bt maize growth and development as affected by temperature and drought stress. In Agronomy Journal, vol. 92, no. 5, pp. 1027-1035. DOI: 10.2134/ agronj2000.9251027x

XU, Z. - HENNESSY, D.A. - SARDANA, K. - MOSCHINI, G.C. 2013. The realized yield effect of genetically engineered crops: U.S. maize and soybean. In Crop Science, vol. 53, pp. 735-745. DOI: 10.2135/cropsci2012.06.0399

YANNI, S.F. - WHALEN, J.K. - MA, B.-L. 2011. Field-grown $\mathrm{Bt}$ and non-Bt corn: Yield, chemical composition, and decomposability. In Agronomy Journal, vol. 103, no. 2, pp. 486-493. DOI: 10.2134/agronj2010.0367

Received: January 24, 2018 